\title{
Subclinical atherosclerosis in young persons horizontally infected with HIV-1 during infancy
}

\author{
Augustin Cupsa, Florentina Dumitrescu*, Dina Maria Cupsa, Andreea Cristina Stoian, L Giubelan, Irina Niculescu, \\ Cristina locu
}

From 17th International Symposium on HIV and Emerging Infectious Diseases (ISHEID)

Marseille, France. 23-25 May 2012

\section{Objectives}

To evaluate subclinical atherosclerosis and to identify the cardiovascular risk (CVR) profile in young adults horizontally infected with HIV-1 during infancy.

\section{Methods}

Retrospective randomized study carried out between 31.12.2009 and 30.06.2010 on 56 HIV infected persons (HIP) parenterally infected with HIV-1 during 19881990, following ART, under surveillance of HIV/AIDS Regional Center - Craiova. Variables followed: history and clinical data, traditional and additional CVR factors, metabolic, immunological and virusological parameters, inflammation markers (hs-CRP), ultrasound data regarding carotid intima-media thickness (IMT). Twenty-six HIV-seronegative young adults were assigned as control group (CG) for metabolic parameters, hs-CRP and IMT.

\section{Results}

General characteristics of the group: average age $=20.82$ \pm 1.1 years, equal distribution by gender, 47 HIP (83.93\%) classified as clinical and/or immunological AIDS, 26 HIP (46.43\%) with CD4 $>500 / \mathrm{mm}^{3}, 40$ HIP (71.43\%) with undetectable RNA-HIV when evaluated, average ART duration $=9.09 \pm 3.2$ years, average number of ART regimens $=3.2 \pm 1.63,40$ HIP $(71.43 \%)$ experienced to protease inhibitors (PIs). In HIP - hs$\mathrm{CRP}=2.17 \mathrm{mg} / \mathrm{l}$, equivalent with a moderate CVR, statistically different compared with CG ( $<<0.0001)$; IMT = $0.76 \pm 0.12 \mathrm{~mm}$ in HIP vs $0.6 \pm 0.11 \mathrm{~mm}$ in CG. From the traditional CVR factors dyslipidemia levels were higher in the HIP group vs. CG $(\mathrm{p}<0.0001)$. In HIP, linear analysis of the evaluated parameters identified direct

* Correspondence: dumitrescu_florentina@yahoo.com

Infectious Diseases at University of Medicine and Pharmacy From Craiova, Craiova, Romania correlations between hs-CRP- erytrocites sedimentation rate (ESR) $(\mathrm{p}=0.04)$, number of ART regimens and PIs exposure $(p=0.007)$, IMT $(p=0.000)$ and HIV-RNA $(\mathrm{p}=0.000)$ and also between IMT - triglycerides $(\mathrm{p}=0.004)$, PIs exposure $(\mathrm{p}=0.004), \mathrm{CD} 8+(\mathrm{p}=0.0000)$ and HIV-RNA ( $\mathrm{p}=0.001)$.

\section{Conclusions}

Young HIP have had an average value of hs-CRP equivalent with a moderate CVR; the CVR profile in young seropositive infected with HIV-1 during infancy includes elevated triglycerides, ESR, CD8+, HIV-RNA values and long time of PIs exposure. IMT in young HIP experienced to ART suggests a premature "aging" of the vessel by about two decades.

Published: 25 May 2012

doi:10.1186/1742-4690-9-S1-P132

Cite this article as: Cupsa et al:: Subclinical atherosclerosis in young persons horizontally infected with HIV-1 during infancy. Retrovirology 2012 9(Suppl 1):P132.

Submit your next manuscript to BioMed Central and take full advantage of:

- Convenient online submission

- Thorough peer review

- No space constraints or color figure charges

- Immediate publication on acceptance

- Inclusion in PubMed, CAS, Scopus and Google Scholar

- Research which is freely available for redistribution 